\title{
EFFICIENCY OF A NATURE-LIKE BYPASS CHANNEL FOR RESTORING LONGITUDINAL CONNECTIVITY FOR A RIVER-RESIDENT POPULATION OF BROWN TROUT
}

Jamie R. Dodd ${ }^{1 *}$, Ian G. Cowx ${ }^{1} \&$ Jon D. Bolland ${ }^{1 *}$

${ }^{1}$ University of Hull International Fisheries Institute

University of Hull, Hull, HU6 7RX

+44 (0)1482 466429

J.Bolland@hull.ac.uk

I.G.Cowx@hull.ac.uk

J.R.Dodd@Outlook.com

${ }^{*}$ Authors to whom correspondence should be addressed 


\section{ABSTRACT}

Man-made, physical barriers have disrupted longitudinal connectivity for migratory fish in many river systems throughout the world for centuries. These barriers are considered to be a key reason for the decline of many fish species in river systems. To date, most research to ease movement of anadromous salmonids past such barriers to help dwindling populations has focused on the use of technical fishways. More recently emphasis has been placed on nature-like fishways to enable a wider range of fish species to bypass these barriers, but few studies have examined their efficacy. In this study, Passive Integrated Transponder (PIT) telemetry was used to assess the upstream-directed movements of 111 river-resident brown trout (length, $151-510-\mathrm{mm}$ ) into and through a 150-m long, nature-like bypass on the River Aire, England. Attraction (51\%), entrance (86\%), passage (78\%) and exit (97\%) efficiencies were high, and trout of a wide range of sizes entered and exited (197 $-510 \mathrm{~mm})$ the pass across a wide range of flows (entrance $=3.55-67.44 \mathrm{~m}^{3} \mathrm{~s}^{-1}$ and exit $=3.89-35.5 \mathrm{~m}^{3} \mathrm{~s}^{-1}$ ). There was evidence that two trout inhabited the pass during the day, entering at sunrise and exiting at sunset. This information is important to improve understanding of fish pass performance, thus informing future best practice guidance of fish passage designs.

Key words: fish passage, barrier, Salmo trutta, telemetry, PIT 


\section{INTRODUCTION}

Uninterrupted longitudinal connectivity enables species and populations to move between suitable habitats, shaping aquatic communities (Hilty et al., 2006). For centuries man-made physical barriers such as weirs and dams have been constructed for the purposes of navigation, power generation and water abstraction (Katopodis and Aaland, 2006). For example, the Environment Agency in England and Wales have developed a database of almost 26, 000 obstructions within the waterways (Environment Agency, 2010). These barriers have impacted upon longitudinal connectivity and disrupted migration of fish in riverine ecosystems worldwide (Petts, 1984; Calles and Greenberg, 2009; Noonan et al., 2012; Williams et al., 2012). The disruption of longitudinal connectivity has caused declines in numerous fish species globally (Petts 1984; Cowx and Welcomme, 1998; Lucas et al., 1999; Lucas and Baras, 2001). The loss of connectivity impacts on the ability of fish move between feeding and spawning grounds (Lucas and Baras, 2001; Amoros and Bornette, 2002) which can effect recruitment success and lead to a reduction in gene flow between populations (Pelicice et al., 2015). Considerable efforts are now focused on addressing these problems and ways to ameliorate the impacts through construction of fish passes and easement of fish migration (Larinier, 1998; Northcote, 1998; Branco et al., 2014).

Total removal of a barrier (Kanehl et al., 1997; Catalano et al., 2007; Burroughs et al., 2010) is the preferred option to remediate longitudinal connectivity, but this cannot always be achieved due to factors such as flood control (Kurby et al., 2005), abstraction and loss of other services for which the barrier was created. Therefore, to ameliorate the potential effects barriers have on interrupting fish migratory pathways and disconnecting habitats, numerous fish pass designs have been developed to ease fish passage and improve longitudinal connectivity (Clay 1995; Lucas and Baras, 2001; Larinier et al., 2002; Roscoe and Hinch, 2010; Bunt et al., 2012). To date, most efforts to ease movement of anadromous salmonids has focused on the use of highly engineered technical fishways (i.e. pool and weir, pool and slot, and Denil), but Noonan et al., (2012) found they rarely achieve 100\% fish passage 
efficiency, normally within the range of $22-71 \%$. They found passage efficiency decreases with increased slope and that pool and weir designs achieved highest passage efficiency results. More recently, however, nature-like bypass channels have received attention (Jungwirth, 1996; Wang and Hartlieb, 2011; Williams et al., 2012) because morphology and water velocities are designed to be similar to those of a natural stream (Parasiewicz et al., 1998), and thus should, in theory, permit free passage of all fish (Eberstaller et al., 1998; Calles and Greenberg, 2005) and present benefits to the wider biodiversity, such as invertebrates and nematoda (Gustafsson et al., 2013).

There is, however, a dearth of investigations into the efficiency of fish passes, especially for nature-like fish pass solutions where the majority of studies relate to anadromous salmonid fishes (Roscoe and Hinch, 2010; Bunt et al., 2012; Noonan et al., 2012; O'Hanley et al., 2013), with a paucity of information on potamodromous and river-resident species through a nature like bypass. Where studies have been carried out, they suggest variable rates of passage efficiency with entrance and exit configuration, attraction flows and hydraulic conditions in the pass and fish size as the main factors affecting efficiency (Calles and Greenberg, 2007; Steffensen et al., 2013; Tummers et al., 2016). However, few studies attempt to investigate all these factors, across a wide range of flows and all seasons during the same investigation.

The free passage of migratory fishes throughout river systems is a key requirement of the European Union Water Framework Directive (WFD) (EC; 2000/60/EEC) because many water bodies throughout Europe are failing to meet environmental targets of Good Ecological Status (GES) or Potential (GEP) due to the presence of barriers. A large number of fish passes have been and are currently being constructed to overcome WFD failures but these are often not assessed for their efficacy or optimal design. There is thus an urgent need to assess the efficacy of all fishway designs to determine if they are operationally effective for all species and inform future designs. One such scheme is the nature-like bypass channel at Rodley Weir on the River Aire in Yorkshire, northern England. This study explores the performance of Rodley Weir nature-like bypass channel to allow free passage for a river-resident population 
of brown trout (Salmo trutta L.), using Passive Integrated Transponder (PIT) telemetry. More specifically, the objectives were to: 1) quantify attraction, entrance, passage and exit and efficiencies; 2) establish the influence of fish size on approaches and movements into and through the fish pass; and 3) evaluate the timing of movements in relation to time after release and environmental conditions (flow and temperature). Such information is critical for improving the design of such passes and inform management decisions on their suitability as a solution for various scenarios where such fish easements may be considered.

\section{MATERIALS AND METHODS}

\subsection{Study site}

The study was conducted between October 2013 and January 2015 on the River Aire, which runs from its source in North Yorkshire (53.843807, -002.812065), through major conurbations, including Bradford, Castleford and Leeds, to its confluence with the River Ouse at Airmyn $(53.726818,-000.90824701)$. The River Aire is $114 \mathrm{~km}$ long with a catchment area of $1100 \mathrm{~km}^{2}$, has 34 weirs situated along its length, of which 11 are regarded as key barriers to fish movements. Steps are now being taken to improve longitudinal connectivity of the river for fish, which for centuries has been fragmented by largely impassable man-made obstructions. One such example is the 50-m wide, 1.8-m high weir at Rodley (53.819763, 001.645892), which was largely impassable to upstream migrating fish. 


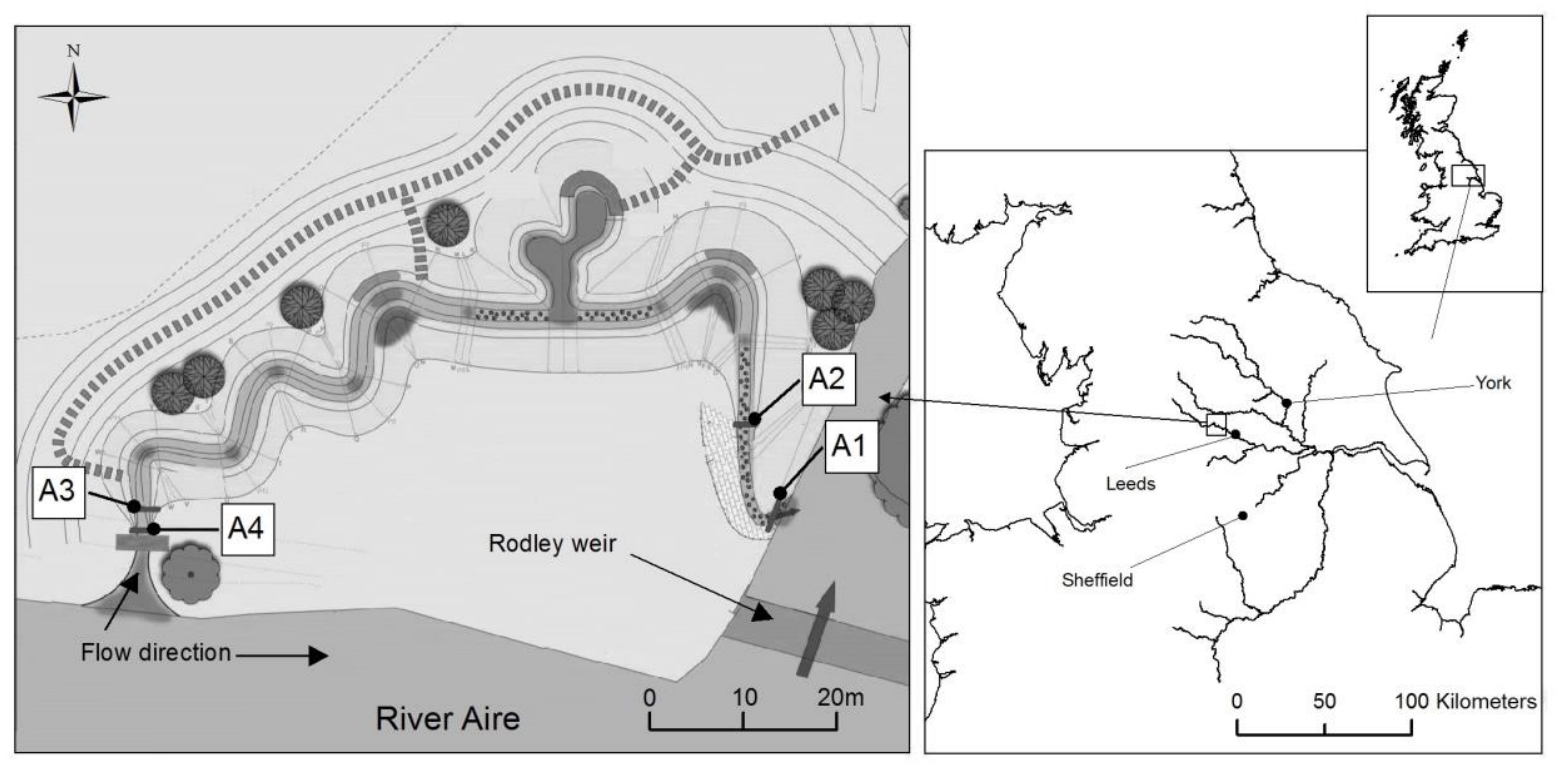

Figure 1: Location and design of the nature-like bypass at Rodley Weir. A1-A4 show location of antennae. Shaded circles represent trees and dashed line represents a footpath. (Fish pass design drawing courtesy of Yorkshire Water and ARUP).

A nature-like bypass channel was constructed at Rodley in the summer of 2013 . It is $150-\mathrm{m}$ long, average slope of $0.688^{\circ}$ and located on the north bank of the River Aire at Rodley Nature Reserve, adjacent to the weir (Figure 1). The downstream section of the fish pass (1.8-m wide $x$ 15-m length) is constructed of vertical concrete-block banks, the middle section contains 12 low-head (100-150-mm) notched vertical steps, gentle sloping landscaped banks and an area of backwater habitat. The upstream section (2.5-m wide $\times 3-\mathrm{m}$ length) was constructed from steel pilings.

\subsection{Sampling and tagging procedure}

Initially, an attempt was made to capture fish downstream of Rodley Weir in August 2013, but this was unsuccessful and was presumed to be the consequence of two pollution incidents in the preceding weeks. Consequently, brown trout were captured using electric fishing from four sites upstream of Rodley Weir (Appendix 1) on 10 - 11 October 2013 and translocated to 350$\mathrm{m}$ downstream of the weir. In addition, brown trout were captured from the 400-m long reach downstream of Rodley Weir on 30 June 2014. Fish were caught either whilst wading or from 
a boat with a single anode using pulsed DC $(200 \mathrm{~V}, 50 \mathrm{~Hz}, \sim 1.5 \mathrm{~A})$ electric fishing equipment, powered by a 2 kVA generator.

Fish caught from each site were initially monitored for any signs of stress before being placed in a holding tank, which was transported over the short journey to Rodley Nature Reserve. On arrival, fish were moved into an aerated holding tank containing fresh river water for a period of one hour, during which time they were again monitored for any signs of stress before undergoing surgery.

All brown trout were $>150-\mathrm{mm}$ and were tagged with 23-mm (half-duplex, 23.0-mm long x 3.4mm diameter, 0.6-g weight in air) PIT tags (Appendix 1). Larsen et al. (2013) reported a 100\% survival and tag retention rate for $>90-\mathrm{mm}$ Atlantic salmon (Salmo salar L.) tagged with 23$\mathrm{mm}$ PIT tags. Prior to tagging in the field, fish were anaesthetised using buffered tricaine methanesulphonate (MS-222). Once anaesthetised the fork length was measured $(\mathrm{mm})$ and recorded. During surgery fish were placed ventral side up in a clean V-shaped foam support. The skin of the fish was disinfected with a dilute iodiphore wipe. Tags were tested with a hand held detector, disinfected with alcohol and rinsed with distilled water before being inserted into the body cavity through a 5-mm long ventro-lateral incision made with a scalpel, anterior to the muscle bed of the pelvic fins. After the surgery, fish were continuously monitored in a well aerated tank of fresh river water. Once fish had regained balance and were actively swimming, they were released back into the river approximately 350-m downstream of Rodley Weir. All fish were treated in compliance with the UK Animals (Scientific Procedures) Act 1986 Home Office licence number PPL 60/4400.

\subsection{Monitoring}

Four fixed location, cross-channel, swim-through half-duplex PIT antennae were installed during the study; two antennae were installed at each of the upstream and downstream ends of the nature-like bypass channel, enabling direction of movement to be recorded (Figure 1). All antennas interrogated full channel width and depth at all river levels during the study. 
Specifically, Antenna 1 (A1) was located at the downstream entrance, Antenna 2 (A2) was 10 m upstream of the first antenna, Antenna 3 (A3) was located 5-m downstream of the fish passage exit and Antenna 4 (A4) was $\sim 1 \mathrm{~m}$ downstream of the steel pilings at the upstream exit to the fish pass. A4 could not be located any closer to the upstream exit as the steel pilings would interfere with the antenna's PIT tag read range. Antennae were constructed from 6-mm diameter copper cable, connected to manual tuning boards (Oregon RFID) attached to a multiantenna data logger (Oregon RFID), synchronously interrogated 10 times per second and powered by two $110 \mathrm{Ah}$, deep-cycle, lead-acid batteries connected in parallel, which were charged by three 90 Watt solar panels. The tag horizontal detection range (20 - 30-cm away from the antenna's vertical plane) was tested during initial set-up and each site visit (on average once per month) to ensure the read range of the interrogated water column had not decreased. Every time a tag was detected, the date, time, detection period, unique tag ID number and antenna number were recorded and stored on a SD card in the data logger; these were manually downloaded during site visits.

The upstream (A3 and A4) and downstream (A1 and A2) pairs of antennae were operational for $88 \%$ and $97 \%$ of the study, respectively, with all four antennas not operational consecutively for $0.2 \%$ of the study. Periods of non-operation were caused by damage during high flow events and low battery power during periods of insufficient sunlight for solar panels to recharge batteries. Antenna A1, A2 and A3 detection efficiencies were 98.0\% (48/49), $80.0 \%$ (39/47) and 66.7\% (30/45), respectively, based on known location (tagging location or previous and subsequent antenna record) of tagged fish. Fish location and movement direction during periods of antenna non-operation were deduced using detections on other operational PIT antennas and subsequent detection location. For example, during December 2013 and January 2014, A3 and A4 were non-operational and could not be repaired due to high river levels presenting a health and safety risk. During this time, fish last detected on A2 were assumed to have passed upstream if they were not subsequently detected on A1. This approach was corroborated when the fish pass was drained on 14 January 2014 to repair A3 
and A4 and no fish left the pass in a downstream direction. Further, one fish assumed to have exited the fish pass in an upstream direction when A3 and A4 were non-operational was next detected on A4 in May 2014. In such instances, the exact date and time of fish movement was not recorded but known fish locations informed attraction, entry, passage and exit efficiencies (see Section 2.4). Fish known to have passed antennas while not operational were hence excluded from analysis on timing of movements between antennas.

\subsection{Data analysis}

Fish pass attraction efficiency was the percentage of the number of tagged brown trout known to have reached the fish pass entrance. Ideally, approach to the weir and fish pass would have been monitored to ensure only motivated fish were studied and account for mortality and downstream emigration but this was not technically possible (main river was too wide and deep). Entrance efficiency was the percentage of fish known to have reached the fish pass entrance that subsequently entered. Passage efficiency was the percentage of fish known to have entered the fish pass that exited the fish pass in an upstream direction. There were concerns that upstream moving fish would not pass through the upstream exit, which was narrower than the majority of the pass (Figure 1). Therefore, exit efficiency was calculated as the percentage of fish known to have reached the fish pass exit that were not subsequently detected moving back downstream.

A Mann-Whitney $U$ test was performed on time between release and first detection to assess the difference in motivation to move through the pass between fish translocated from upstream of the weir in October 2013 and captured downstream of the weir in June 2014. The effect of fish length (at tagging) on the attraction and passage success were tested using binary logistic regression. Too few fish failed to enter and exit the pass to perform binary logistic regressions. Fish tagged in October 2013 detected in the fish pass after March 2014 and those tagged in June 2014 were excluded from fish size comparison analysis because growth rates and thus fish size were unknown. Brown trout growth between early October and the end of March is usually minimal (Bacon et al., 2005; Jonsson and Jonsson, 2011). Binary logistic regression 
was conducted using $R$ version 3.3.1 (R Core Team, 2012). A Mann-Whitney $U$ test compared flows when fish entered but did not ascend the fish pass with fish that entered and ascended. Mann-Whitney $U$ tests were conducted using SPSS 22.

The flow duration curve is a common graphical technique used for assessing the frequency distribution of flow within a river system (Croker, et al., 2003). Flow duration curves were derived from the Armley gauging station (53.802051, -001.580039), 7.4-km downstream of the fish pass, to determine the range of flows over which entrance and fish passage occurred. Flows from Armley were highly correlated with water depth in the fish pass $\left(R^{2}=0.95\right)$. Temperature was recorded at 15-min intervals on a Tinytalk logger (Gemini Data Loggers; www.geminidataloggers.com) located in the bypass channel. Sunrise and sunset times at Rodley were gathered from HM Nautical Almanac Office (http://astro.ukho.gov.uk/surfbin/first beta.cgi).

\section{RESULTS}

A total of 111 wild brown trout $(151-510-\mathrm{mm})$ were caught, PIT tagged and released into the River Aire. Fifty seven of the 111 tagged brown trout were attracted to the downstream end of the fish pass (attraction efficiency $=51 \%$ ). Of the 57 fish known to have reached the fish pass entrance, 49 subsequently entered (entrance efficiency $=89 \%$ ). Thirty-eight of the 49 tagged fish that entered the pass exited the pass in an upstream direction (passage efficiency $=78 \%$ ). All but one of the 39 fish that reached the fish pass exit left in an upstream direction (exit efficiency $=97 \%$ ), i.e. one fish was subsequently detected moving back downstream. One of the 38 fish that left the fish pass in an upstream direction descended the pass two days later.

Four fish were detected at the entrance to the fish pass (A1) on the day of release, with one fish taking 27 min to move between the release location and the downstream end of the fish pass. A further 12 fish were detected at the entrance of the pass over the next two days, 30 fish within the first week after release and another 11 fish during the following week. Fifteen fish took more than two weeks before they were first detected at the fish pass entrance, with 
seven of the fish tagged in October 2013 not being detected in the first year after release; 397 days was the longest period between release and first detection. The time to first detection in the fish pass was comparable between fish translocated from upstream of the weir in October 2013 and those captured downstream of the weir in June 2014 (Mann-Whitney $U$ test: $Z=$ $-.085, n=57, P=0.943)$.

Of the 48 fish that were detected entering the pass (A2), six fish were detected on $A 2$ within one minute of being first detected at the entrance (A1), with the shortest time between first detection on both antennas being $25 \mathrm{sec}$. Thirty fish entered the fish pass between 1 and 8 minutes after first detection on A1 and six more fish entered in less than 30 minutes. Three individuals entered the pass within a day after first detection and one fish took five days, but was detected at the entrance (A1) on two other days before entering. Two others took a month and 44 days, neither of which were detected at the fish pass entrance in the period between first detection and entry.

When fish entered the pass for the first occasion, the fastest time between leaving A1 and first detection on A2 was 10 seconds (fish speed $=1.14 \mathrm{~m} \mathrm{~s}^{-1}$ ), with the slowest time judged to be $30 \min 41 \mathrm{sec}$.

Twenty-four fish detected at the fish pass entrance (A1) were also detected at the exit (A4), with $18(75 \%)$ of these fish taking less than one hour between last detection on both antennas and $13 \mathrm{~min} 27 \mathrm{sec}$ being the quickest. A further three fish took between one and two hours, one fish took six hours, one fish took 67 hours and one took 286 hours to ascend the pass.

Of the fish tagged in October 2013 and detected before end-March 2014, a significant logistic regression model (Coefficient $=0.008$, Std. Error $=0.003, z$ statistic $=2.487, P=0.013$ ) was created for fish pass attraction (Figure 2). The 50\% and $90 \%$ probability of attraction (P50 and P90) were 258-mm and 512-mm, respectively. The model for passage (P50 = 207-mm and P90 $=383-\mathrm{mm} ;$ Coefficient $=0.017$, Std. Error $=0.006, \mathrm{z}$ statistic $=1.869, P=0.062)$ was 
insignificant (Figure 2), and thus suggest movements through the fish pass was not influenced by length of fish tagged.
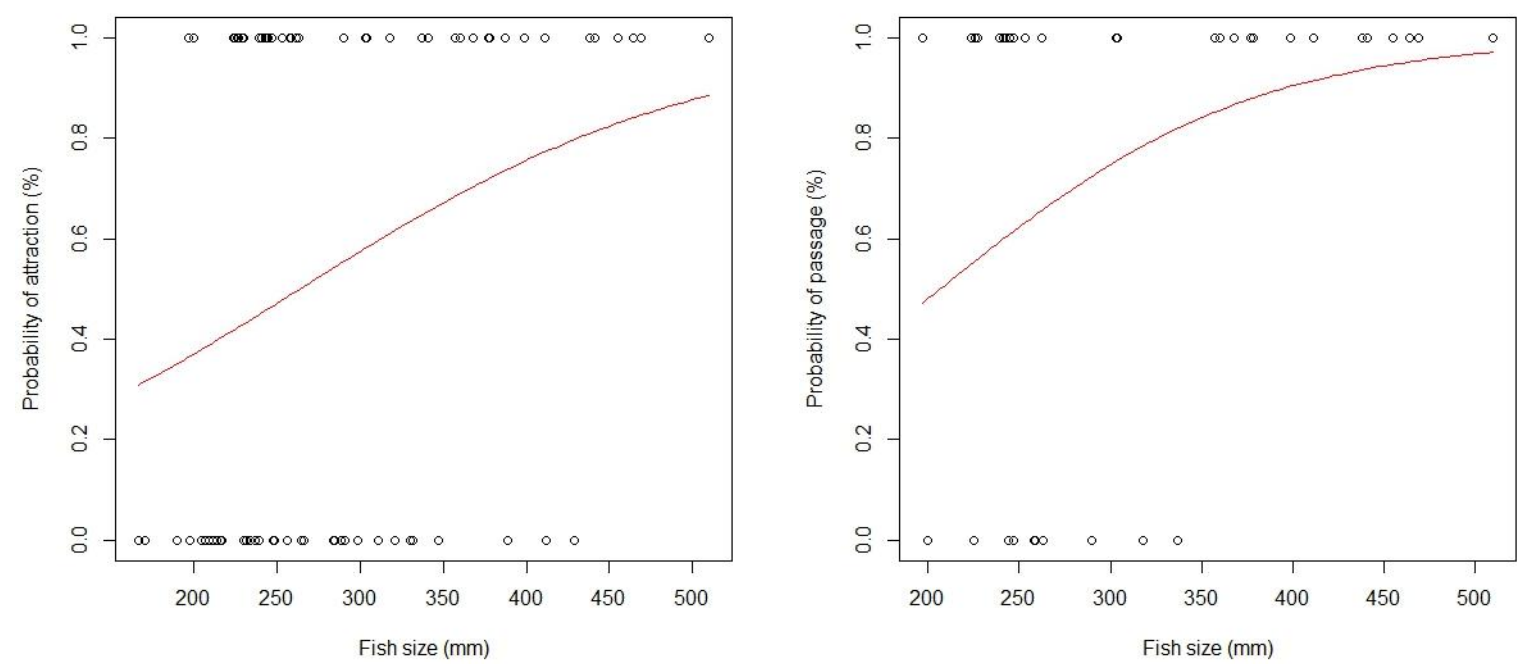

Figure 2: Binary logistic regression model of probability of attraction (left) and passage (right) for each individual's body length $(\mathrm{mm})$.

Fish entered (first detection on A2) and exited (last detection on A4) the fish pass at river flows between $Q_{2}-Q_{97}\left(67.44-3.55 \mathrm{~m}^{3} \mathrm{~s}^{-1}\right)$ and $\mathrm{Q}_{13}-\mathrm{Q}_{93}\left(35.5-3.89 \mathrm{~m}^{3} \mathrm{~s}^{-1}\right)$, respectively (Figure 3). The time to enter the fish pass (last detection on A1 and first detection on A2) was not correlated with prevailing flow. The highest proportion (36\%) of upstream exit movements made by trout in the fish pass occurred between flows of $6-10 \mathrm{~m}^{3} \mathrm{~s}^{-1}\left(Q_{54}-Q_{76}\right)$, which was also the most frequent flow band found through the study period (27\%) (Figure 4). Flows were not significantly different between fish which entered but did not ascend with fish that entered and ascended (Mann-Whitney $U$-test: $Z=-.142, n=35, P=0.903$ ). Daily average water temperature ranged from $4-18^{\circ} \mathrm{C}$ during the study, with fish detections occurring during water temperatures of $6-17^{\circ} \mathrm{C}$. The highest proportion (25\%) of upstream passage movements occurred at $12^{\circ} \mathrm{C}$, with a disproportionally high proportion of fish moving when river temperature was $9^{\circ} \mathrm{C}(15 \%), 10^{\circ} \mathrm{C}(18 \%)$ and $11^{\circ} \mathrm{C}(13 \%)$ (Figure 4). 

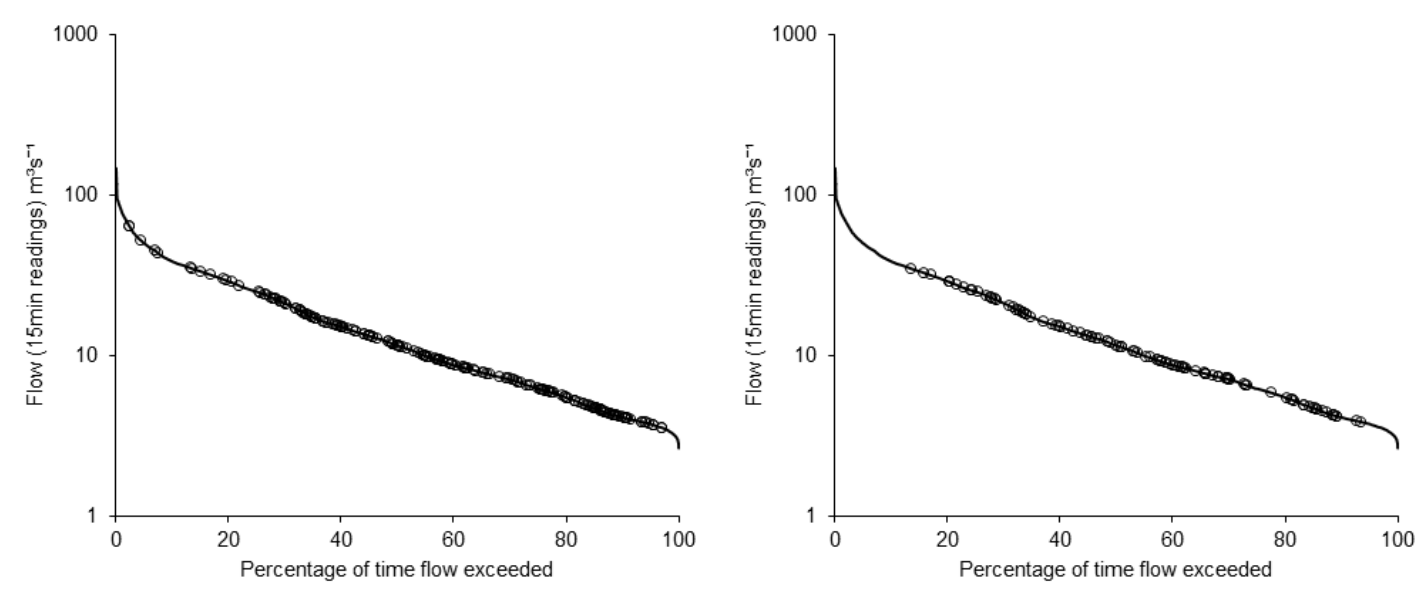

Figure 3: Timing of entry into the fish pass (left; first detection on A2) and passage (right; last detection on A4) for brown trout in relation to percentage of time the flow was exceeded.
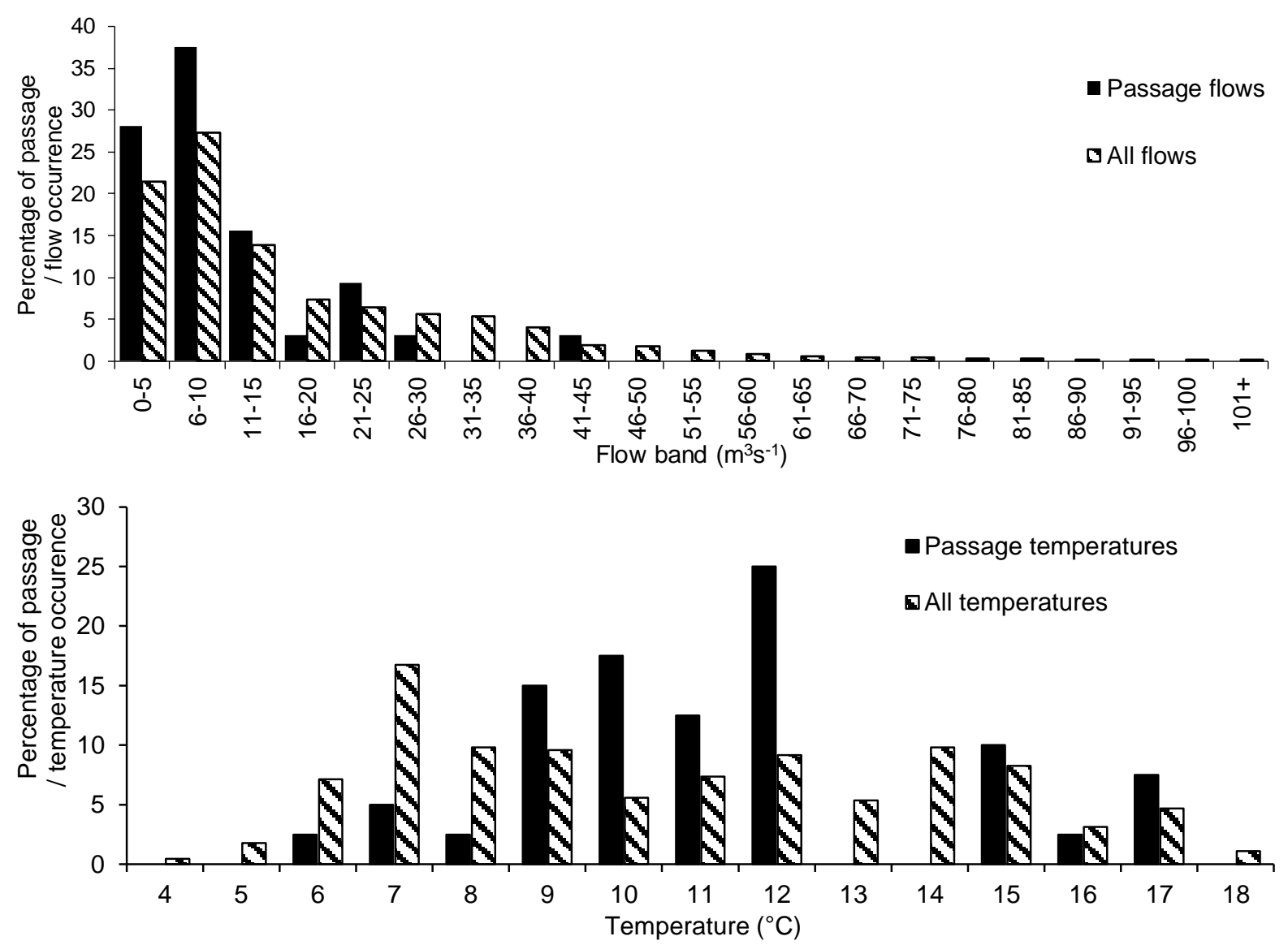

Figure 4: Percentage of upstream passages during flow $\left(\mathrm{m}^{3} \mathrm{~s}^{-1}\right.$ : top) and temperature ( ${ }^{\circ} \mathrm{C}$; bottom) bands (black) and flow and temperature occurrence throughout the study (stripes).

Forty nine fish entered the fish pass at least once, twenty fish entered twice and four fish entered eight times. One individual entered the upstream end of the pass on 28 consecutive 
days (2 - 29 July 2014), spending the day inside the pass with entrances exclusively occurring in the morning ( $86 \%$ within an hour of sunrise) and exiting in an evening (84\% within an hour of sunset) (Figure 5). However, on three days (8, 10 and 25 July 2014) the fish also spent the night inside the fish pass before exiting the following morning but reentered within five minutes. The most number of times an individual fish entered the downstream end of the pass was on 84 different occasions, predominantly between 24 February and 31 May 2014, with 74\% of entrances within an hour of sunrise and $44 \%$ of exits within an hour of sunset (Figure 5). 


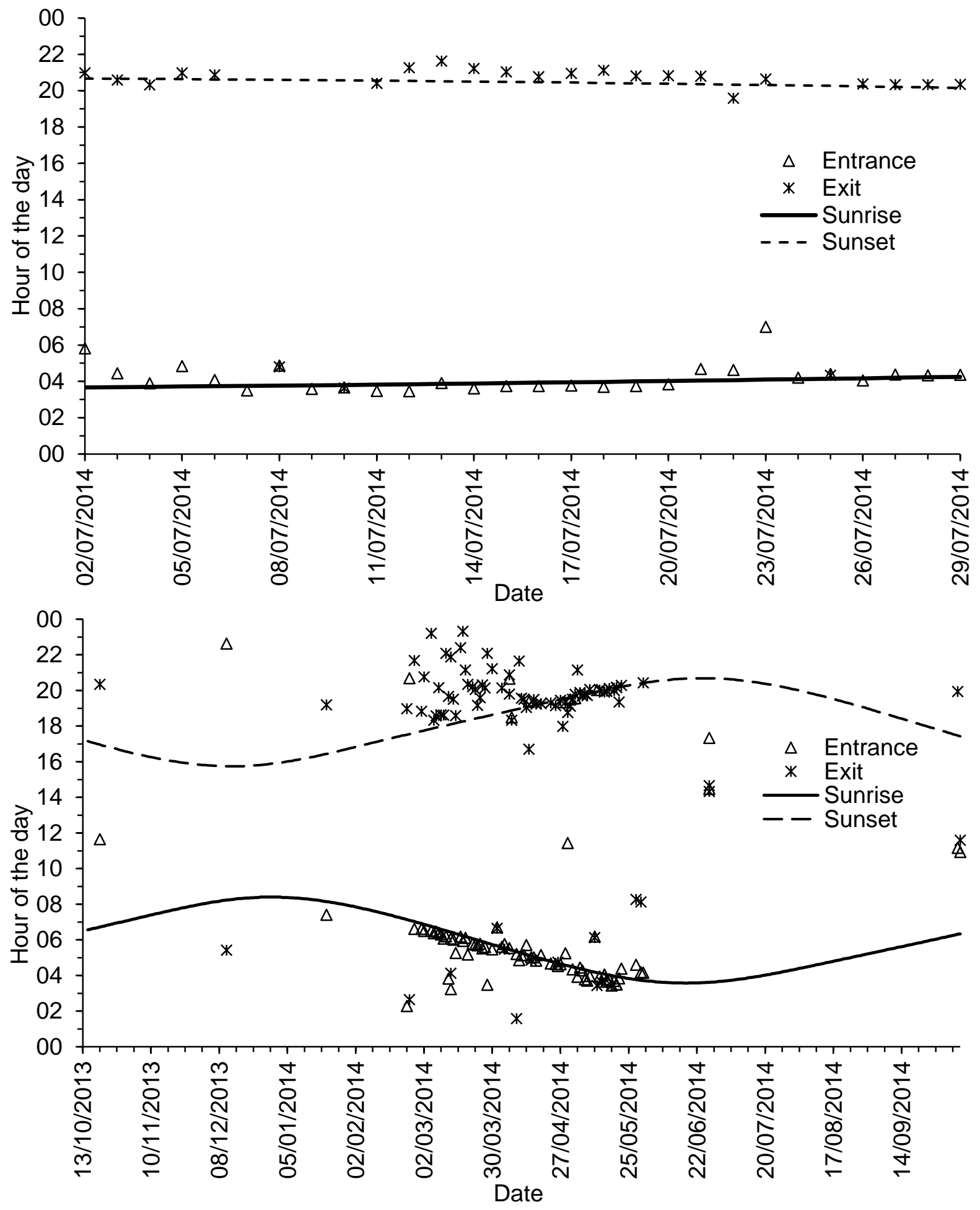

Figure 5: The time of fish pass entrance (triangle) and exit (cross) of two brown trout (single plot per fish) in relation to the time of sunrise (solid line) and sunset (dashed line).

A fish tagged on 11 October 2013 was recaptured during a fish survey downstream of the weir on 30 June 2014; 262 days after it was tagged and had not been detected in the fish pass. The fish was in good condition; the tagging wound had healed and the fish had grown 
from $261-\mathrm{mm}$ to $409-\mathrm{mm}$, i.e. $148-\mathrm{mm}$ growth. It went on to ascend the pass on 31 October 2014,385 days after it was tagged. 


\section{DISCUSSION}

Disruption of longitudinal connectivity caused by dams and weirs prevents free movement of diadromous, potamodromous and river-resident fish species between the habitats required to complete their life cycles, and has culminated in the decline of many species globally (Petts 1984; Katopodis, 1992; Godinho and Kynard, 2009; Brown et al., 2013). Part of the problem is that remediation measures are rarely considered for potamodromous and river-resident fish species and most efforts are generally targeted at upstream migrating anadromous species. Although potamodromous and river-resident species can benefit indirectly by retrofitting of fish easements, but they are not always suitable for the full range of species present (Benitez et al., 2015; Tummers et al., 2016). The best solution to enhance fish movements of a full range of species is barrier removal, but this is seldom possible and thus uninterrupted fish movements and migration must be managed using engineered fish pass solutions, with nature-like bypass channels believed to be the preferred option as they resemble a natural river. Evidence supporting this assumption and advocating use of nature-like fish passes is necessary given the additional cost and land required for construction as sub-standard fish passes are ecologically damaging (because it is assumed the solution is in place) and financially expensive to rectify. This investigation advances the knowledge surrounding the performance of a nature-like bypass channels by quantifying attraction, entrance, passage and exit efficiency and the influence of fish size and river flow on fish movement.

Attraction efficiency (51\%) was comparable to the 50 and $53 \%$ reported for anadromous brown trout approaching the Upper Finsjo nature-like bypass channel on the River Emån in 2001 and 2002, respectively (Calles and Greenberg, 2005). A higher attraction efficiency (91 \%) was also reported for anadromous brown trout (Aarestrup et al., 2003) on Tirsbaek stream, Denmark. While Steffensen et al., (2013) reported attraction efficiency of a nature-like bypass ranged from 58 to $100 \%$ for warm water potamodromous species in the Indian Creek, Ontario, Canada. Although considered unlikely, the fish studied during this investigation could have spawned in the reach downstream of the weir and thus may explain why attraction efficiency 
was lower than reported in other investigations. Given significantly larger fish were attracted to the pass it is possible that smaller tagged fish were sub-adult and thus did not perform a spawning migration.

One factor that can influence the attraction efficiency of the pass is the design and location of the entrance. The fish pass entrance was perpendicular to the weir face, contrary to English, French and German guidance, which states it should be parallel to weir flow (Larinier, 2002; Armstrong et al., 2010; Adam and Bosse, 2014), although fitting perpendicular is recommended in Belgium and the Netherlands (Kroes and Monden, 2004). Thorstad et al. (2008) indicated that flow protruding from a fishway entrance should be easily detectable by fish, this should in theory act as a guidance towards the entrance (Castro-Santos et al., 2009). In order to achieve this Armstrong et al. (2010) recommended that a minimum of $5 \%$ of the annual daily flow should be directed through the pass to provide adequate attraction flows. Efforts to increase attraction efficiency could also include altering the location or the dimensions of the entrance. For example, Bunt (2001) showed that widening and repositioning Denil fishways on the Grand River, Ontario, closer to the weir face (fish were attracted to weir discharge) resulted a 3-fold increase in fishway use by pumpkinseed (Lepomis gibbosus L.). However, such modifications may narrow the range of flows fish enter the pass, to the detriment of the high entrance efficiency.

Passage efficiency (78\%) in this study was higher than $0-57 \%$ reported for many potamodromous species in a small Ontario stream, Canada (Steffensen et al., 2013) and the $60 \%$ reported for anadromous brown trout in Denmark (Aarestrup et al., 2003). However, it was lower than the $92-100 \%$ reported for anadromous brown trout in two nature-like bypasses in Sweden (Calles and Greenberg, 2005). Both lower and higher passage efficiencies have also been reported for brown trout in Switzerland (1.9 - 100\%) (Weibel and Peter, 2013) and at Cobourg Brook, Canada (100\%) (O'Connor et al., 2003) with block ramps and vertical-slot passes, respectively. Fish length is known to influence swimming performance (Clough and Turnpenny, 2001; Katopodis et al., 2001; Green et al., 2011) and 
passage efficiency (Noonan et al., 2012), but the size of fish that ascended Rodley Weir nature-like bypass channel was not significantly different to those that entered but left via the downstream route. It is also possible that fish did not complete the full ascent of the pass at Rodley because they were undergoing exploratory behavior and returned to their established territories.

Entrance efficiency was high ( $86 \%$ ) and fish entered the bypass channel across a very wide range of flows $\left(Q_{2}-Q_{97}\right)$. Notwithstanding this, the fish pass entrance was predominantly slack water during the extreme high flow events (personal observation at $Q_{0.4}$ ), and thus fish may have entered the pass for flow refuge (FAO, 2002). Further, exit efficiency (97\%) was high and fish exited the pass in an upstream direction between flow exceedances of $Q_{13}-Q_{93}$. Turbulence at the narrow exit may have restricted movements (personal observation at $Q_{0.4}$ ), as reported by Lucas et al. (1999) and Bunt et al. (2000), but flows during passage and nonpassage events were similar. Therefore, fish that did not ascend probably did so as a natural behavior to exit the pass via a downstream route rather than the event being a failed ascent. Furthermore, fish were frequently detected in the pass throughout the course of the investigation, across a range of flows and during both day and night. Of particular interest is the movement of two brown trout that were seen predominantly entering the fish pass at sunrise and leaving at sunset. Other studies have also observed fish occupying nature-like bypasses (Jungwirth, 1996; Santos et al., 2005; Calles and Greenberg, 2007), thus adding credence to the argument that nature-like bypass channels resemble natural river channel hydromorphology. While not considered a concern during this investigation, Kim et al. (2016) trapped predators inside a nature-like bypass channel and Agostinho et al. (2012) reported a fish ladder in Brazil was a hotspot for predation, and thus fish inhabiting fish passes could be more vulnerable to predation.

The translocation of brown trout is known to initiate a homing instinct (Armstrong and Herbert, 1997) which could be a reason for the high number of translocated fish observed moving through the pass within two weeks of release. Indeed, Forty et al. (2016) suggested 
translocated brown trout could be used provide a method of quick assessment for fish passage structures. Alternatively, fish movements through the pass in autumn may have occurred as part of a brown trout spawning migration (Frost and Brown, 1967). During this investigation the time between release and first detection at fish pass was comparable between fish translocated from upstream of the weir in October 2013 and captured downstream of the weir in June 2014. Both groups of tagged fish were hence considered motivated to move, albeit possibly for different reasons. Regardless of what motivated the fish to move, the findings demonstrate that brown trout were physically capable of finding, entering and swimming through the nature-like bypass channel.

Water temperature plays an important role in the upstream movement of salmonid species (Jensen and Aass, 1995; Moore et al., 2012), and has been found to be a main factor in the upstream movement of brown trout (Santos et al., 2005). Fish during this study were recorded to perform a large percentage of upstream movements during water temperatures between 9 $-12^{\circ} \mathrm{C}$. These temperatures are in accordance to the findings of other studies assessing brown trout upstream movements (Ovidio et al., 2007; Forty et al., 2016).

In conclusion, Rodley Weir nature-like bypass had comparable attraction efficiency and high entrance, passage and exit efficiencies for brown trout when compared to other studies investigating nature-like bypass channels. These metrics also compare favorably with movements through engineered fish passes (Linløkken, 1993; Thiem et al., 2012). Although significantly smaller individuals were not attracted to the pass the fish that entered the pass and exited in an upstream direction were of comparable size to those that left in a downstream direction. In addition, fish moved through the pass across a wide range of flows and there was evidence that fish inhabited the pass. These findings were particularly encouraging because river-resident fish that inhabit the river downstream of a barrier may need to use a fish pass at all flows whereas adult anadromous species tend to migrate through a reach / around a barrier during elevated flows. Therefore, we conclude that nature-like bypasses should be employed elsewhere to overcome legislative failures, e.g. WFD, by increasing longitudinal connectivity 
across a range of flows for small river-resident species while also providing favorable conditions for fish to inhabit. This case study demonstrates how a man-made fish pass engineered to function naturally enabled sustainable use of environmental resources, findings which are directly relevant to catchment managers globally.

\section{Acknowledgements}

The authors would like to thank all Hull International Fisheries Institute staff involved in electric fishing, tagging and assisting on the project. lan Wellby for assistance during tagging and Rodley Nature Reserve for access to the site. The research was supported by Yorkshire Water, with project management and fish pass design from ARUP. Special thanks to the reviewers for their valuable comments on a draft of this manuscript.

\section{REFERENCES}

Aarestrup, K., Lucas, M. C., Hansen, J. A., 2003. Efficiency of a nature-like bypass channel for sea trout (Salmo trutta) ascending a small Danish stream studied by PIT telemetry. Ecology of Freshwater Fish, 12, 160-168. doi:10.1034/j.1600-0633.2003.00028.x

Adam, B., Bosse, R., 2014. Fish Passes - Design, dimensions and monitoring. DWARegelwerk. Merkblatt DWA-M509. [in German]

Agostinho, A. A., Agostinho, C. S., Pelicice, F. M., Marques, E. E., 2012. Fish ladders: safe fish passage or hotspot for predation? Neotropical Ichthyology, 10, 687-696.

Amoros C., Bornette G., 2002. Connectivity and biocomplexity in waterbodies of riverine floodplains. Freshwater Biology, 47, 761-776.

Armstrong, J. D., Herbert, N. A., 1997. Homing movement of displaced stream-dwelling brown trout. Journal of Fish Biology, 50, 2, 445-449. doi: 10.1111/j.1095-8649.1997.tb01372.x

Armstrong, G. S., Aprahamian, M. W., Fewlings, G. A., Glough, P. J., Reader, N. J., Varallo, P. V. 2010. Environment Agency Fish Pass Manual: Guidance Notes on the Legislation, Selection and Approval of Fish Passes in England and Wales. Bristol: Environment Agency

Bacon, P. J., Gurney, W. S. C., Jones, W., Mclaren, I. S., Youngson, A. F., 2005. Seasonal growth patterns of wild juvenile fish: Partitioning variation among explanatory variables, based on individual growth trajectories of Atlantic salmon (Salmo salar) parr. Journal of Animal Ecology, 74, 1-11. doi:10.1111/j.1365-2656.2004.00875.x

Benitez, J. P., Nzau Motondo, B., Dierckx, A., Ovidio, M., 2015. An overview of potamodromous fish upstream movements in medium-sized rivers, by means of fish passes monitoring. Aquatic Ecology, 49(4), 481-497. 
Branco, P., Segurado, P., Santos, J. M., Ferreira, M. T., 2014. Prioritizing barrier removal to improve functional connectivity of rivers. Journal of Applied Ecology, 51, 1197-1206. doi:10.1111/1365-2664.12317

Brown, J. J., Limburg, K. E., Waldman, J. R., Stephenson, K., Glenn, E. P., Juanes, F., Jordaan, A., 2013, Fish and hydropower on the U.S. Atlantic coast: failed fisheries policies from half-way technologies. Conservation Letters, 6(4), 280-286.

Bunt, C. M., Cooke, S. J., Mc Kinley, R. S., 2000. Assessment of the Dunnville fishway for passage of walleyes from Lake Erie to the Grand River, Ontario. Journal of Great Lakes Research, 26, 482-488. doi: 10.1016/ S0380-1330(00)70709-X

Bunt, C. M., 2001. Fishway entrance modifications enhance fish attraction. Fisheries Management and Ecology, 8, 95-105. doi:10.1046/j.1365-2400.2001.00238.x

Bunt, C. M., Castro-Santos, T., Haro, A., 2012. Performance of fish passage structures at upstream barriers to migration. Journal of River Research and Applications, 28, 457-478. doi:10.1002/rra.1565

Burroughs, B. A., Hayes, D. B., Klomp, K. D., Hansen, J. F., Mistak, J., 2010. The Effects of the Stronach Dam Removal on Fish in the Pine River, Manistee County, Michigan. Transactions of the American Fisheries Society, 139, 1595-1613. doi: 10.1577/T09056.1

Calles, E. O., Greenberg, L. A., 2005. Evaluation of nature-like fishways for re-establishing connectivity in fragmented salmonid populations in the River Emån. Journal of River Research and Applications, 21, 951-960. doi: 10.1002/rra.865

Calles, E. O., Greenberg, L. A., 2007. The use of two nature-like fishways by some fish species in the Swedish River Emån. Ecology of Freshwater Fish, 16, 183-190. doi: 10.1111/j.1600-0633.2006.00210.x

Calles, O., Greenberg, L., 2009. Connectivity is a two-way street-the need for a holistic approach to fish passage problems in regulated rivers. Journal of River Research and Applications, 25, 1268-1286. doi: 10.1002/rra.1228

Castro-Santos, T., Cotel, A., Webb, P.W., 2009. Fishway evaluations for better bioengineering: an integrative approach. In: A.J. Haro, K.L. Smith, R.A. Rulifson, C.M. Moffitt, R.J. Klauda, M.J. Dadswell, R.A. Cunjak, J.E. Cooper, K.L. Beal, T.S. Avery (eds) Challenges for Diadromous Fishes in a Dynamic Global Environment. Vol. Symposium 69., American Fisheries Society, Bethesda, MD, pp. 557-575.

Catalano, M., Bozek, M., Pellett, T., 2007. Effects of dam removal on fish assemblage structure and spatial distributions in the Baraboo River, Wisconsin. North American Journal of Fisheries Management, 27, 519-530. doi:10.1577/M06-001.1

Clay, C., 1995. Design of Fishways and Other Fish Facilities. Boca Raton: CRC Press, Inc.

Clough, S., Turnpenny, A., 2001. Swimming speeds in fish, phase 1 technical report Accessed on the 25/01/2016 at:

https://www.gov.uk/government/uploads/system/uploads/attachment_data/file/290589/s w2-026-tr1-e-e.pdf 
Cowx, I. G., Welcomme, R. L., (eds) 1998. Rehabilitation of Rivers for Fish. Oxford: FAO and Fishing News Books, Blackwell Science, 260 pp.

Croker, K. M., Young, A. R., Zaidman, M. D., Rees, H. G., 2003. Flow duration curve estimation in ephemeral catchments in Portugal. Hydrological Sciences Journal, 48(3), 427-439. doi: 10.1623/hysj.48.3.427.45287

Eberstaller, J., Hinterhofer, M., Parasiewicz, P., 1998. The effectiveness of two nature-like bypass channels in an upland Austrian river. In: M. Jungwirth, S. Schmutz., S. Weiss (eds) Fish Migration and Fish Bypasses. Oxford: Fishing News Books, Blackwell Publications, pp. 363-383.

EA (2010). Mapping hydropower opportunities and sensitivities in England and Wales. Environment Agency Technical Report, 67 pp.

FAO, 2002. Fish passes - Design, dimensions and monitoring. Food and Agriculture Organization of the United Nations in arrangement with DVWK, Rome

Forty, M., Spees, J., Lucas, M.C., 2016. Not just for adults! Evaluating the performance of multiple fish passage designs at low-head barriers for the upstream movement of juvenile and adult trout Salmo trutta. Ecological Engineering, 94, pp.214-224

Frost, W. E., Brown, M. E., 1967. The trout. Collins, London, England.

Godinho, A. L., Kynard, B., 2009. Migratory fishes of Brazil: Life history and fish passage needs. Journal of River Research and Applications, 25(6), 702-712.

Green, T. M., Lindmark, E. M., Lundström, T. S., Gustavsson, L. H., 2011. Flow characterization of an attraction channel as entrance to fishways. Journal of River Research and Applications, 27, 1290-1297. doi: 10.1002/rra.1426

Gustafsson, S., Österling, M., Skurdal, J., Schneider, L. D., Calles, O., 2013. Macroinvertebrate colonization of a nature-like fishway: The effects of adding habitat heterogeneity. Ecological Engineering, 61, pp.345-353

Hilty, J. A., Lidicker, W. Z. Jr., Merenlender, A., 2006. Corridor ecology: the science and practices of linking landscapes for biodiversity conservation. Inland press.

Jensen, A.J., Aass, P., 1995. Migration of a Fast-Growing Population of Brown Trout (SalmoTrutta L) through a Fish Ladder in Relation to Water-Flow and Water Temperature. Regulated Rivers-Research \& Management, 10(November), pp.217-228.

Jonsson, B., Jonsson, N., 2011. Ecology of Atlantic Salmon and Brown Trout. Habitat as a template for life histories. Fish and Fisheries Series 33. Springer Science + Business media.

Jungwirth, M., 1996. Bypass channels at weirs as appropriate aids for fish migration in rhithral rivers. Regulated Rivers: Research and Management, 12, 483-492. doi: 10.1002/(SICI)1099-1646(199607)12:4/5<483::AID-RRR402>3.0.CO;2-B

Kanehl, P. D., Lyons, J., Nelson, J. E., 1997. Changes in the Habitat and Fish Community of the Milwaukee River, Wisconsin, Following Removal of the Woolen Mills Dam. North 
American Journal of Fisheries Management, 17, 387-400. doi:10.1577/15488675(1997)017<0387:CITHAF>2.3.CO;2

Katopodis, C., 1992. Introduction to fishway design. Working Doc. Freshw Inst, Cent and Arct Reg, Fish and Oceans Can, p70

Katopodis, C., Kells, J. A., Acharya, M., 2001. Nature-Like and Conventional Fishways: Alternative Concepts? Canadian Water Resources Journal, 26, 211-232. doi:10.4296/cwrj2602211

Katopodis, C., Aadland, L. P., 2006. Effective dam removal and river channel restoration approaches. International Journal of River Basin Management, 4(3), 153-168

Kim, J-H., Yoon J-D., Baek, S-H., Park S-H., Lee J-W., Lee, J-A., Jang, M-H., 2016. An efficiency analysis of a nature-like fishway for freshwater fish ascending a large Korean river. Water, 8, 3. doi:10.3390/w8010003

Kroes, M. J., Monden, S., 2004. Fish migration - a manual for restoration in Flanders and the Netherlands. Ministry of the Flemish community, Brussels, Belgium. ISBN 90-8032456-6. 207 pp. [in Dutch]

Kurby, M. J., Fagan, W. F., ReVelle, C. S., Graf, W. L., 2005. A multiobjective optimization model for dam removal: an example of trading off salmon passage with hydropower and water storage in the Willamette basin. Advances in Water Resources, 28, 845-855.

Larinier, M., 1998. Upstream and Downstream Fish Passage Experience in France. In: M. Jungwirth, S. Schmutz., S. Weiss (eds) Fish Migration and Fish Bypasses. Oxford: Fishing News Books, Blackwell Publications pp. 127-145.

Larinier, M., Travade, F., Porcher, J.P., 2002. Fishways: biological basis, design criteria and monitoring. Bull. Fr. Pêche Piscic 364 suppl.: 208

Larinier, M., 2002. Location of Fishways. Bull. Fr. Pêche Piscic. (2002) 364 suppl.: 39-53.

Larsen, M.H., Thorn, A. N., Skov, C., Aarestrup, K., 2013. Effects of passive integrated transponder tags on survival and growth of juvenile Atlantic salmon Salmo salar. Animal Biotelemetry, 1, 19. doi:10.1186/2050-3385-1-19

Linløkken, A., 1993. Efficiency of fishways and impact of dams on the migration of grayling and brown trout in the Glomma river system, south eastern Norway. Regulated Rivers: Research and Management, 8, 145 - 153

Lucas, M. C., Mercer, T., Armstrong, J. D., McGinty, S., Rycroft, P., 1999. Use of a flat-bed passive integrated transponder antenna array to study the migration and behaviour of lowland river fishes at a fish pass. Fisheries Research, 44, 183-191. doi:10.1016/S01657836(99)00061-2

Lucas, M. C., Baras, E., 2001. Migration of Freshwater Fishes. Oxford: Blackwell Science, 420 pp.

Moore, A., Bendall, B., Barry, J., Waring, C., Crooks, N., Crooks, L., 2012. River temperature and adult anadromous Atlantic salmon, Salmo salar, and brown trout, Salmo trutta. Fisheries Management and Ecology, 19(6), pp.518-526. 
Noonan, M. J., Grant, J. W. A., Jackson, C. D., 2012. A quantitative assessment of fish passage efficiency. Fish and Fisheries, 13, 450-464. doi: 10.1111/j.14672979.2011.00445.x

Northcote, T., 1998. Migratory Behaviour of Fish and its significance to movement through riverine fish passage facilities In: M. Jungwirth, S. Schmutz., S. Weiss (eds) Fish Migration and Fish Bypasses. Oxford: Fishing News Books, Blackwell Publications pp. 3-18.

O'Connor, L. M., Pratt, T. C., Hallett, A., Katopodis, C., Bergstedt, R.A., Hayes, D. B., McLaughlin, R. L., 2003. A performance evaluation of fishways at sea lamprey barriers and controlled modifications to improve fishway performance. Progress report Ann Arbor, MI Great Lakes Fishery Commission.

O'Hanley, J. R., Wright, J., Diebel, M., Fedora, M. A., Soucy, C. L., 2013. Restoring stream habitat connectivity: A proposed method for prioritizing the removal of resident fish passage barriers. Journal of Environmental Management, 125, 19-27. doi: 10.1016/j.jenvman.2013.02.055

Ovidio, M., Capra, H., Philippart, J.C., 2007. Field protocol for assessing small obstacles to migration of brown trout Salmo trutta, and European grayling Thymallus thymallus: A contribution to the management of free movement in rivers. Fisheries Management and Ecology, 14(1), pp.41-50.

Parasiewicz, P., Eberstaller, J., Weiss, S., Schmutz, S., 1998. Conceptual guidelines for nature-like bypass channels In: M. Jungwirth, S. Schmutz., S. Weiss (eds) Fish Migration and Fish Bypasses. Oxford: Fishing News Books, Blackwell Publications pp. 348-362.

Pelicice, F. M., Pompeu. P. S., Agostinho., A. A., 2015. Large reservoirs as ecological barriers to downstream movements of Neotrophical magratory fish. Fish and Fisheries, 16, 697715

Petts, G. E., 1984. Impounded rivers: perspectives for ecological management. Chichester, United Kingdom; John Wiley and Sons.

R Core Team, 2012. R: A Language and Environment for Statistical Computing. R Foundation for Statistical Computing, Vienna, Austria, URL http://www.R-project.org/.

Roscoe, D. W., Hinch, S. G., 2010. Effectiveness monitoring of fish passage facilities: historical trends, geographic patterns and future directions. Fish and Fisheries, 11, 12 33. doi: 10.1111/j.1467-2979.2009.00333.x

Santos, J. M., Ferreira, M. T., Godinho, F. N., Bochechas, J., 2005. Efficacy of a nature-like bypass channel in a Portuguese lowland river. Journal of Applied Ichthyology, 21, 381388. doi: 10.1111/j.1439-0426.2005.00616.x

Steffensen, S. M., Thiem, J. D., Stamplecoskie, K. M., Binder, T. R., Hatry, C., LangloisAnderson, N., Cooke, S. J., 2013. Biological effectiveness of an inexpensive nature-like fishway for passage of warmwater fish in a small Ontario stream. Ecology of Freshwater Fish, 22, 374-383. doi: 10.1111/eff.12032

Thiem, J. D., Binder, T. R., Dumont, P., Hatin, D., Hatry, C., Katapodis, C., Stamplecoskie, K. M., Cooke, S. J., 2012. Multispecies fish passage behaviour in a vertical slot fishway on 
the Richelieu River, Quebec, Canada. Journal of River Research and Applications, 29(5), 582-592

Thorstad, E. B., Økland, F., Aarestrup, K., Heggberget, T.G., 2008. Factors affecting the within-river spawning migration of Atlantic salmon, with emphasis on human impact. Review Fish Biology Fisheries, 18, 345-371

Tummers, J. S., Hudson, S., Lucas, M. C., 2016. Evaluating the effectiveness of restoring longitudinal connectivity for stream fish communities: towards a more holistic approach. Science of the Total Environment, 569-570, 850-860

Wang, R. W., Hartlieb, A., 2011. Experimental and field approach to the hydraulics of naturelike pool-type fish migration facilities. Knowledge and Management of Aquatic Ecosystems, 400, 05. doi: 10.1051/kmae/2011001

Weibel, D., Peter, A., 2013. Effectiveness of different types of block ramps for fish upstream movement. Aquatic Sciences, 75, 251-260.

WFD, (2000)/60/EC, The Water Framework Directive. Accessed on 25/01/2016 at: http://ec.europa.eu/environment/water/water-framework/index_en.html

Williams, J. G., Armstrong, G., Katopodis, C., Larinier, M., Travade, F., 2012. Thinking like a fish: A key ingredient for development of effective fish passage facilities at river obstructions. Journal of River Research and Applications, 28, 407-417. doi: 10.1002/rra.1551 
Appendix 1: Summary of date of capture, site name, location (Lat, Long), number caught $(n)$, fork length (mean \pm S.D. (range), mm) and in-channel displacement distance (km) of PIT tagged brown trout

\begin{tabular}{cllll}
\hline Capture date & Site name & Location (Lat, Long) & $n$ & Length (mean \pm SD (range), mm) \\
\hline $10 / 10 / 2013$ & Esholt Hall & $53.856726,-001.726962$ & 16 & $357.1 \pm 93.4(224-510)$ \\
$11 / 10 / 2013$ & Hirst Wood Weir & $53.837778,-001.773738$ & 31 & $273.5 \pm 61.6(212-441)$ \\
$10 / 10 / 2013$ & Crossflats & $53.859124,-001.854797$ & 8 & $311.3 \pm 71.7(245-438)$ \\
$11 / 10 / 2013$ & Silsden Bridge & $53.902655,-001.944518$ & 33 & $257.3 \pm 64.2(167-429)$ \\
$30 / 06 / 2014$ & Rodley Weir & $53.819763,-001.645892$ & 23 & $184.6 \pm 24.7(151-239)$ \\
\hline
\end{tabular}

